\title{
Reproductive seasonality and sexual dimorphism in green turtles
}

\author{
B. J. Godley*, A. C. Broderick, R. Frauenstein, F. Glen, G. C. Hays \\ Marine Turtle Research Group, School of Biological Sciences, University of Wales, Singleton Park, Swansea SA2 8PP, Wales, UK
}

\begin{abstract}
The temporal distribution of nesting and mating in green turtles Chelonia mydas at Ascension Island $\left(7^{\circ} 57^{\prime} \mathrm{S}, 14^{\circ} 22^{\prime} \mathrm{W}\right)$ in the South Atlantic is described. Mathematical description of the seasonal pattern of nesting showed extreme similarity between seasons, and evidence is presented to support the hypothesis that observed patterns are driven by prevailing environmental temperature. Mating was observed to begin before nesting and follow a pattern consistent with a modelled seasonal influx of suitable females into the annual breeding population. When available data on male size are compared with that of females from the same population $(\mathrm{n}=12$ populations), a pronounced and consistent sexual dimorphism, with males being smaller than females, is highlighted in all populations. The possible mechanisms behind the evolution of such a pattern are discussed.
\end{abstract}

KEY WORDS: Chelonia mydas $\cdot$ Mating $\cdot$ Breeding $\cdot$ Ascension Island $\cdot$ Sea turtles $\cdot$ Atlantic

Resale or republication not permitted without written consent of the publisher

\section{INTRODUCTION}

Although tropical regions experience relatively constant environmental conditions year-round in comparison with temperate and polar regions, they usually demonstrate some level of seasonality. This has effects on the reproductive biology of animal species, leading to the evolution of defined breeding seasons in many species (Baker 1938, Wikelski et al. 2000). The green turtle Chelonia mydas is distributed circumglobally in the tropics and subtropics and reproductive efforts display a marked seasonality in all populations (Hirth 1997). Nesting usually occurs in the warmest months, and even in the few populations that nest year-round there is a marked annual peak (Miller 1997). The majority of the adult life cycle is spent in foraging grounds, which are often great distances from the nesting grounds. Both sexes make cyclical remigrations to the breeding grounds, usually at the interval of several years in females (reviewed by Hirth 1997), possibly with a greater frequency in males (Balazs 1983, Limpus 1993). Where undertaken, genetic studies

*E-mail: mtn@swan.ac.uk have shown natal philopatry to be in operation in females (Bowen et al. 1992) and, although possibly to a lesser extent, in males (Karl et al. 1992, FitzSimmons et al. $1997 a$,b). Natal philopatry contributes to genotypic divergence among populations, leading to the formation of discrete breeding populations.

As mating occurs in the sea, knowledge of marine turtle mating systems is rudimentary and, barring work carried out on the Australian and Hawaiian breeding populations of green turtles (Balazs 1980, Limpus 1993, Jessop et al. 1999), based on captive studies and largely anecdotal accounts. Although records exist of males intercepting receptive females en route to nesting sites (Meylan et al. 1992), behaviour interpreted as courting and copulation generally occur close to nesting beaches, often in lagoonal habitats (Harrison 1954, Hendrickson 1958, Frazier 1971, Booth \& Peters 1972, Bustard 1972, Broderick \& Godley 1997). In addition, there can be areas that are preferred courting locations for regional nesting populations, with females dispersing to nesting beaches after mating (Balazs 1980, Limpus 1993). The mating system in the green turtle has been described as 'scramble polygamy' (Jessop et al. 1999), with males competitively searching for receptive females rather than undertak- 
ing territorial defence or combat as the primary mate acquisition techniques. Individual males have been observed mating with several females in the same season (Booth \& Peters 1972, Limpus 1993, FitzSimmons 1997b), and paternity analysis has suggested that, although multiple paternity of clutches may be common (Peare et al. 1994), it is not universal (FitzSimmons 1998). As in many chelonids (Carpenter \& Ferguson 1977) courtship and mating are relatively stereotyped in marine turtles (see Frick et al. 2000 for review). The first detailed field descriptions of the ethology of courtship in green turtles were given by Booth \& Peters (1972), and these were augmented by detailed studies under farmed conditions (Ulrich \& Parkes 1978, Wood \& Wood 1980, Comuzzie \& Owens 1990). In general, female choice appears to be in operation with males undertaking what has been described as elaborate courtship behaviour. It was once thought that the sperm was stored from mating in one year for the successive breeding season (Carr \& Hirth 1962). Although it is possible that sperm could be stored, it is widely felt that mating is primarily directed at fertilising the clutches in the proximate season, with copulation being undertaken prior to nesting (Owens 1980). In the wild, the timing of mating in the green turtle has largely been described qualitatively as largely occurring early in the nesting season (e.g. Hendrickson 1958, Carr et al. 1974, Green 1994). An exception is Limpus (1993), who suggested that in the Capricorn Bunker Group, Australia, courting turtles were generally found in October and November, and occasionally in September and December. Detailed observations of green turtles in captivity found most mating to occur approximately $30 \mathrm{~d}$ prior to first nesting of any individual (Wood \& Wood 1980), consistent with the delay from mating to first nesting described by Booth \& Peters (1972). It appears that, although females can be receptive for a period of $15 \mathrm{~d}$, most mating is carried out over a period of some 2 to $4 \mathrm{~d}$ (Booth \& Peters 1972, Ulrich \& Parkes 1978, Wood \& Wood 1980, Comuzzie \& Owens 1990). Given the information available at the time, Owens (1980) hypothesised that, 'the peak of mating should occur about 1 mo prior to the peak of first clutch nesters'.

Although originally described by Darwin (1874), there has been a resurgence in the research interest in the processes behind sexual selection in recent decades, with studies focussing on the role in the evolution of mating systems and sexual dimorphism in addition to the empirical testing of these ideas (e.g. Kolata 1977). Among vertebrates, some authors have looked for correlates within phylogenetic groups, which might help explain the ecological and physiological mechanisms behind sexual dimorphism, e.g. mammals (Clutton-Brock et al. 1977), shorebirds (Jehl
\& Murray 1986), raptorial birds (Paton et al. 1994), snakes (Shine 1978), amphibia (Shine 1979), and turtles (Berry \& Shine 1980). In their review, Berry \& Shine (1980) found that turtle mating strategies could be classified into 3 major groups which correlated with habitat use and showed patterns of sexual dimorphism consistent with sexual selection theory: terrestrial species were more likely to engage in male combat and demonstrate males which were larger than conspecific females; semi-aquatic and bottom walking species were shown to have larger males than females and behaviour suggestive of forced insemination; aquatic species appeared to have elaborate courtship, suggestive of female choice and almost universally showed sexual dimorphism where males were smaller than females. In all marine turtle species, secondary sexual characteristics are marked with breeding males having a longer prehensile tail with terminal nail (Hendrickson 1958), larger, recurved claws on the front flippers (Hendrickson 1958, Wibbels et al. 1991) and soft, more concave plastra (Wibbels et al. 1991). Although some authors have described a significantly different shape, with males being more elongated (Miller 1989), other authoritative reviews have suggested that there is no sexual dimorphism in size in marine turtles (Carr 1952, Pritchard 1979, Wibbels et al. 1991), which would appear in contradiction to the pattern suggested by Berry \& Shine (1980). There is a growing body of evidence, however, which was first reviewed by Limpus (1993; $\mathrm{n}=2$ breeding populations) and is extended here ( $\mathrm{n}=12$ breeding populations) to suggest that there is sexual dimorphism in green turtles.

The green turtle population breeding at Ascension Island is an excellent model for studying seasonality of reproductive activities, as they are large, conspicuous vertebrates. Both sexes travel great distances from widely distributed foraging grounds (Carr 1975) to a small, localised breeding ground for which detailed environmental data are available (Hays et al. 1999). This massive energetic cost in reaching the breeding site and staying there (there is no feeding available for the herbivorous green turtle surrounding Ascension Island) would suggests that any seasonality of breeding and nesting will be highly evolved to maximise reproductive output in both sexes. Temporal distribution of female reproductive effort can be relatively easily monitored by enumerating nests on beaches (Mortimer \& Carr 1987, Godley et al. 2001). The population is sufficiently large and the mating areas sufficiently localised so that enough observation of mating can be undertaken to allow meaningful conclusions to be drawn regarding its temporal distribution. We set out to investigate the factors which may lead to the evolution of the existing nesting season and to test the aforementioned hypothesis of Owens (1980) regarding the 
temporal linkage between mating and nesting. In addition, we review the available published and unpublished data on morphometrics in green turtles to discover if the sexual dimorphism that would be expected in a species apparently demonstrating such elaborate courtship is present. We also investigate how this pattern may vary among different breeding populations, given that mean female size can vary greatly at different sites.

\section{MATERIALS AND METHODS}

Study site. Ascension Island $\left(7^{\circ} 57^{\prime} \mathrm{S}, 14^{\circ} 22^{\prime} \mathrm{W}\right)$ is an isolated volcanic peak on the mid-Atlantic ridge that has 32 beaches and coves which are used for nesting by the green turtle Chelonia mydas (Mortimer \& Carr 1987). During the early part of a nesting survey in 1998/99, mating turtles were observed regularly in the bays off the 3 largest beaches (Beaches 1, 12, 27; numbers as per Mortimer \& Carr 1987), which also host the majority of nesting on the island. Since Clarence Bay, enclosed by Long Beach (Beach 12), was by far the most important courting/mating area, demonstrating more courtship activity, by an order of magnitude, than any other site, it was chosen as the locale for our study of mating behaviour.

Mating and male morphometrics. To quantify the seasonality of mating, standard counts were made on 128 d $(60 \%$ of all days; always 3 or more days in each week) between 1 November 1999 and 1 June 2000. Observations were made between 08:00 and 10:00 h GMT. The time of day was standardised to control for differences in glare and sun direction. During the period of study visibility was always good. Surveying was undertaken from a set point at a historical cannon placement at $250 \mathrm{~m}$ elevation, $400 \mathrm{~m}$ behind Long Beach, which commands an excellent view over Clarence Bay, allowing mating pairs to be observed to a distance of $800 \mathrm{~m}$. Using $10 \times 40$ binoculars in a standard scanning pattern, the whole bay could be observed to enumerate the number of mating pairs of turtles. This was repeated at 5 min intervals, for a total of 5 times on each survey day. A mean of the count of mating pairs was taken as an index of mating occurring on that day.

In addition, as part of another study (Hays et al. 2001), on 16 December 1999 and 18 January 2000, a mating pair was captured at sea within $300 \mathrm{~m}$ of Long Beach, using a tangle net $(50 \mathrm{~m} \times 6 \mathrm{~m}$; mesh size $30 \mathrm{~cm})$ set by boat. Females were released and male turtles were then taken ashore onto the beach in the net and carried into a shaded area so that morphometrics, including curved carapace length (CCL), could be obtained. To allow comparison of morphometrics with those from other populations, data were supplemented with values from a thorough review of the literature, unpubl. data from B.J.G. et al. and also data supplied by colleagues. Although data on size of adult males from feeding grounds were available (Caldwell 1962, Witzell 1982, Ross 1985), they were not included. Turtles in foraging areas can have multiple origins (Bass et al. 1998, Lahanas et al. 1998); large immature males can be mistaken for females; and some females may still not have recruited to the breeding population, although already at sizes equivalent to those of small breeding adults.

Nesting. From 1 December 1998 until 31 August 2000, the number of nests recorded on all the beaches was estimated for each day by utilising the methodology of Godley et al. (2001). In addition, in a sample of female turtles $(\mathrm{n}=83)$, both standard CCL and straight carapace length (SCL) were measured (Bolten 1999).

Meteorological information. Meteorological data were made available by the RAF Meteorological Station at Ascension Island Airfield.

\section{RESULTS}

\section{Temporal distribution of nesting}

The temporal distribution of nesting in both the 1998/99 and the 1999/2000 seasons are shown in Fig. 1. Nesting in the 1999/2000 season began on 22 November 1999 and continued until 22 July 2000. Although the magnitude of nesting was slightly less in the latter season, it can be seen that the pattern of nesting

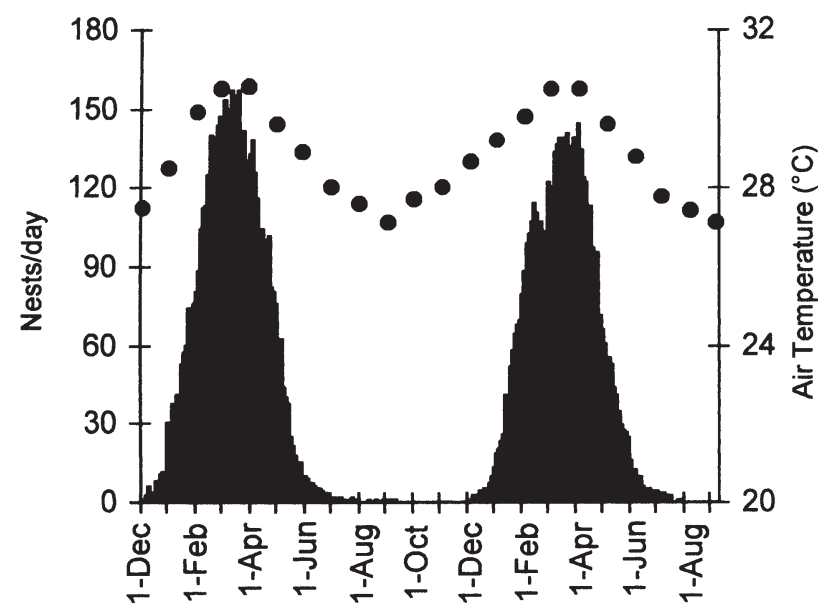

Fig. 1. Estimated number of nests $\mathrm{d}^{-1}$ at the Ascension Island nesting colony between 1 December 1998 and 31 August 2000. (•) Mean monthly maximum air temperature measured at Ascension Island Airfield 


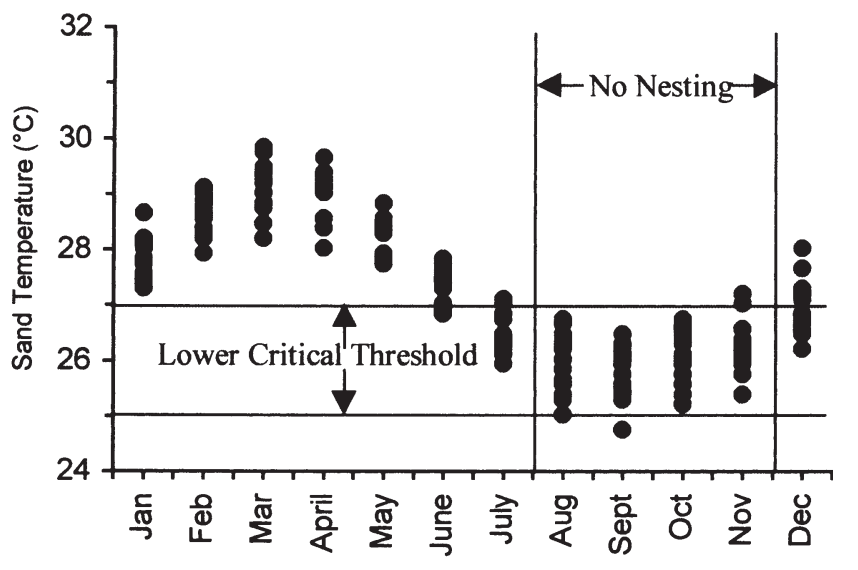

Fig. 2. Monthly mean sand temperature on Long Beach (January 1985 to September 2000) predicted using relationship between monthly mean maximum air temperature measured at Ascension Island Airfield and sand temperature at nest depth on Long Beach (mean monthly sand temperature $\left[{ }^{\circ} \mathrm{C}\right]$ on Long Beach $=1.6+0.908$ mean monthly daily maximum temperature; $F_{1,10}=498, \mathrm{p}<0.001, \mathrm{r}^{2}=0.98$; Hays et al. 1999). Months of negligible or no nesting (August to November) and lower critical threshold of temperature for development (Ackerman 1996) are shown

follows a marked seasonality similar in both years which appears to closely follow a normal distribution.

The reason for the observed seasonality of marine turtle nesting on Ascension might be related to the seasonal pattern of prevailing air and sand temperature. Fig. 1 shows that the peak of nesting is clearly during the warmest months. To further demonstrate this, we used the close relationship between air temperature and sand temperature at nest depth previously described by Hays et al. (1999). We can see that on Long Beach, the single most important nesting site on the island, during the

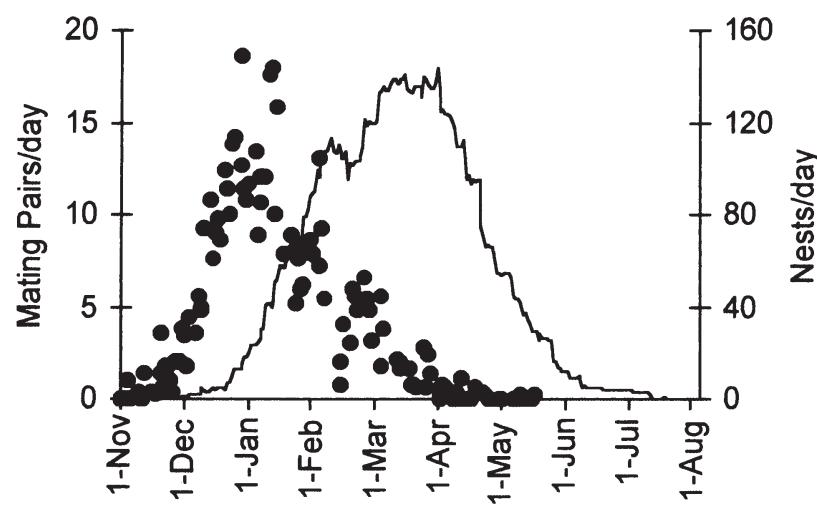

Fig. 3. Seasonality of mating and nesting of green turtles at Ascension in the 1999/2000 nesting season. Line plots estimated daily number of nests throughout Ascension Island. (•) Mean number of mating pairs observed in Clarence Bay on each survey day months of negligible or no nesting (July to October), sand temperatures are close to the lower limit of the thermal tolerance range for marine turtle embryos (25 to $27^{\circ} \mathrm{C}$, Fig. 2 from Ackerman 1996).

Temporal distribution of mating. Mating was observed on 116 or $193(60 \%)$ survey days between 4 November 1999 and 14 May 2000. Fig. 3 shows the temporal distribution of the mean number of mating pairs observed on each survey day in comparison to the estimated number of nests laid $\mathrm{d}^{-1}$. Mating starts before nesting, peaks and declines to a low level before the maximum nesting levels are reached but continues well past the peak of nesting. The last mating activities were observed when the nesting had decayed to a low level.

To compare the pattern of mating with that of nesting, it becomes necessary to more explicitly define the seasonality of nesting. This is difficult, as the day-to-day variations within a seasonal pattern can confound any comparison. We described the seasonal nesting curve by firstly generating the mean date for each season (1998/99: Day 101; 1999/2000: Day 111) according to:

$$
\text { Mean date of season }=\frac{\sum f}{\sum x f}
$$

where $x=$ day of the season and $f=$ number of nests.

The standard deviation $(\delta)$ for each mean date was then calculated (1998/99: $\mathrm{SD}=35.3 ; 1999 / 2000: \mathrm{SD}=$ 36.2) according to Bailey (1981):

$$
\delta^{2}=\frac{1}{\left(\sum f\right) / 1}\left(\sum\left(f x^{2}\right)-\frac{(f x)^{2}}{\sum f}\right)
$$

Following this, the normal distribution for each curve could be fitted according to Bailey (1981):

$$
y=\frac{1}{\delta \sqrt{2 \pi}} \exp \left(-\frac{(x-\mu)^{2}}{2 \delta^{2}}\right)
$$

where $\mu=$ population mean and was substituted by mean for the sample. This data series was then scaled to the maximum value. These modelled distributions were highly correlated with the actual distribution in both years $\left(1998 / 99: \mathrm{r}^{2}=0.99, F_{1,272}=32118.35\right.$, $\left.\mathrm{p}<0.001 ; 1999 / 2000: \mathrm{r}^{2}=0.98, F_{1,242}=11569, \mathrm{p}<0.001\right)$.

If females only mate at the start of the season during a fertile period, approximately $30 \mathrm{~d}$ prior to nesting (Booth \& Peters 1972, Ulrich \& Parkes 1978, Wood \& Wood 1980, Comuzzie \& Owens 1990), it might be expected that the peak of mating would be demonstrated $30 \mathrm{~d}$ prior to the peak of nesting. This is not the case (Fig. 2).

We propose that the number of females being mated at a given time will be related to the rate of change of nesting some $30 \mathrm{~d}$ subsequently. The difference in number of nests between 2 successive days within the season is an index of the relative immigration/emigra- 


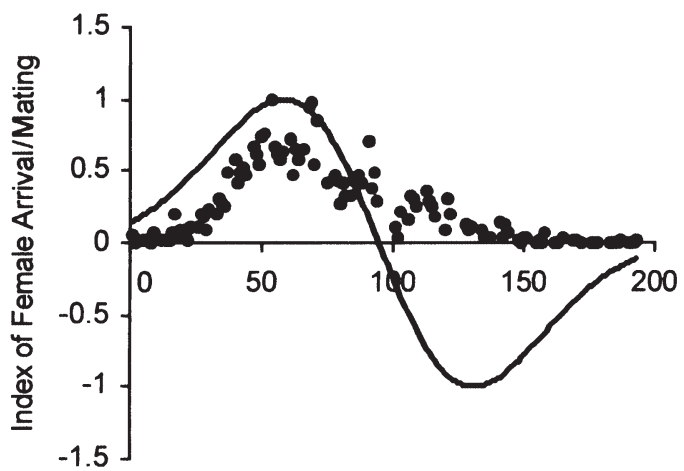

Day of season

Fig. 4. Mating pairs (๑) and relative index of female arrival (solid line) as calculated by degree of change in nesting numbers compared with $30 \mathrm{~d}$ subsequently. Both data sets are scaled to a maximum index value of 1.0

tion from the breeding population. To investigate the role of relative abundance of females available for mating, and the observed levels of mating activity, we calculated the daily change in the number of nests throughout the season based on the curve of the normal distribution of the 1999/2000 season as calculated using the method above. We compared the mean number of mating pairs with the change in nesting numbers $30 \mathrm{~d}$ subsequently (Fig. 4). The modelled data show that mating increases in parallel with the index of female arrival, with coincidental peaks in both measures. As the net influx of females begins to decline to zero (i.e. the peak of nesting), the relative amount of mating also declines, but at a lower rate, with mating activity being observed well into the latter part of the nesting season.

\section{Sexual dimorphism}

Data on the sizes of male and female turtles from a number of populations were collated ( $\mathrm{n}=12$ populations; Fig. 5). Data on size were present in the form of curved carapace length (CCL) and straight carapace length (SCL). In the absence of an existing equation in the literature, we converted SCL to CCL using the equation generated by the analysis of Ascension Island female morphometrics $\left(\mathrm{CCL}=0.83 \mathrm{SCL}+25.4, \mathrm{r}^{2}=0.69, F_{1,81}=\right.$ $178, \mathrm{p}<0.0001)$. The sexual dimorphism index (SDI), i.e. the ratio of CCL of the larger sex (always female in this study) to that of the smaller sex (as per Gibbons \& Lovich 1990) varied little among populations with a range of 1.04 to 1.11 (Mean $\pm \mathrm{SD}=1.07 \pm 0.02$ ). In addition, SDI did not systemically vary with female size (regression, $\mathrm{p}>0.05)$. In all populations there was a clear and consistent pattern of sexual dimorphism, with males being the smaller sex (male CCL $=0.944$ female CCL $-1.0, \mathrm{r}^{2}=$ $\left.0.95 F_{1,10}=198.6, \mathrm{p}<0.001\right)$.

\section{DISCUSSION}

\section{Seasonality}

In the classic overview of the factors leading to the evolution of breeding seasons, Baker (1938) put forward a dichotomy between the 'ultimate' environmental factors, i.e. those upon which selection might act, and the 'proximate' environmental factors, i.e. those which might be used as cues with which the physiological timing of reproduction would be stimulated, e.g. photoperiod or environmental temperature. Owens (1980) suggested the timing of reproduction in female sea turtles will be ultimately defined by factors which will mean that eggs are on the beach at an optimal time, e.g. to ensure that hatching is coincidental with suitable feeding resources or oceanic currents which optimise recruitment. Our evidence strongly suggests that the sand temperature is one such ultimate factor dictating the seasonality of nesting in the population of green turtles nesting at Ascension, with sand temperatures being near or below critical limits for development in the months when little or no nesting occurs. Although our findings are based on over 14 yr of thermal information, we only have data on the seasonality of 2 nesting seasons. It is noteworthy, however, that the observed seasonality is highly consistent with the 2 seasons described by Mortimer \& Carr (1987).

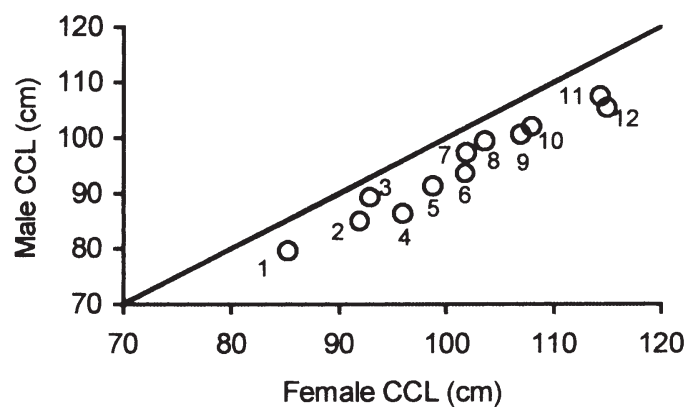

Fig. 5. Mean curved carapace length (CCL) of male vs female turtles from the same breeding population. For females, where morphometric data are not included in the same source as male morphometrics, data are included from Hirth (1997). For males, data are included from: (1) Mexico, Michoacan ( $\mathrm{n}=7$; Rostal et al. 1995); (2) Northern Cyprus, Alagadi ( $\mathrm{n}=3$; for males: A.C.B. \& B.J.G. unpubl. data; for females: Broderick \& Godley 1996); (3) Ecuador, Galapagos (n not given; Green 1994); (4) Turkey, Kazanli ( $\mathrm{n}=6$; B.J.G. unpubl. data, H. Orek pers. comm.); (5) Saudi Arabia, Karan Island ( $=21$; Miller 1989); (6) Federated Micronesia, Yap State $(n=3$; s.p. Kolinsky 1995 pers. comm.); (7) USA, Hawaii ( $\mathrm{n}=2$; Balazs \& Ellis 2000); (8) Costa Rica, Tortuguero $(\mathrm{n}=4$; Ross \& Lageux 1993, Troeng in press); (9) Australia, southern Great Barrier Reef ( $\mathrm{n}=361$; Limpus 1993); (10) Seychelles, Aldabra Atoll $(\mathrm{n}=84$; Frazier 1971); (11) UK, Ascension ( $\mathrm{n}=2$; this study); (12) Brazil, Atol dos Rocas ( $n=48$; C. Bellini pers. comm.). For comparison, the line of equivalence is plotted 
Our data are in concordance with the hypothesis put forth by Owens (1980) regarding the expected temporal occurrence of mating. The nesting season at Ascension is very long, and by the time the peak of nesting has occurred, many of the first turtles to begin laying will have completed their season's efforts and are likely to have left the breeding grounds. In addition, for the period from mating to nesting, Mortimer \& Carr (1987) conservatively estimated the number of clutches laid by individual females on Ascension at 3.0, which with the inter-nesting duration of the order of $14 \mathrm{~d}$ will mean that an average female's stay at the breeding ground is likely to be of the order of $60 \mathrm{~d}$. Thus, as the first females depart, many other females are arriving. This is why we think that the strong correlation between the index of female arrival and mating is present in the first half of the nesting season, with mating continuing once there is a net efflux from the seasonal breeding population. Our data are strongly suggestive of the fact that, where female breeding may be dictated by factors such as temperature, the seasonality of male attendance and mating is likely to be driven by the presence of suitable females.

The proximate factors and thresholds thereof for stimulating the migration to the breeding areas at Ascension may be the same in both sexes. Male and female turtles undertake long migrations to the breeding area, where there is no feeding, leading to a massive energetic cost in both the cost of transport and duration of fasting of the order of some months (Carr \& Hirth 1962, Prange 1976). They must twice undertake a transatlantic swim (Luschi et al. 1998), which is likely to take the order of $6 \mathrm{wk}$ each way, in addition to the period of residence at the breeding grounds. To minimise the cost, females have been shown to rest on the sea floor between nestings (Hays et al. 2000). However, if males competitively search for receptive females and undertake limited combat and mating, energetic limitations will constrain both how long a male may stay at the breeding grounds and how much he will be able to partake in reproductive activities before compromising chances of his survivorship. Survivorship may be impacted by lowering the proportion of individuals completing the transatlantic swim to the foraging grounds and/or surviving until the next breeding season. To maximise reproductive success in males, it might be expected that the timing of arrival at the mating grounds will coincide with the maximum number of available females. Although it is likely that most males will arrive at the same time as the bulk of the females, it may be preferential for some males to arrive earlier and some to stay until all available females are mated as has been recorded in a colonial breeding mammal, the northern elephant seal Mirounga angustirostris, by Le Boeuf \& Reiter (1988).
Detailed viewing of this linkage between nesting and mating would not have been possible without the modelling of the seasonal pattern of nesting by fitting a mathematical function through the distribution. We suggest that this is not only a useful technique for the between-season comparisons of nesting seasonality but could also be of utility for inter-population and even inter-specific comparisons.

\section{Sexual dimorphism}

It is clear from our data that sexual dimorphism exists, with females being larger than males in all mating populations of green turtles, for which data are available. In addition, the narrow range in sexual dimorphism index (SDI) highlighted by the close correlation between adult female size and adult male size is remarkable, given the large range of possible sizes in this species, with mean CCL of populations of adult females ranging from $82 \mathrm{~cm}$ in Mexico to $123 \mathrm{~cm}$ in Brazil (Hirth 1997). This contrasts markedly with studies of the slider turtle Trichemys scripta, where Gibbons \& Lovich (1990) found that the SDI varied markedly among 9 populations studied (range of SDI: 1.15 to 1.55 ; mean $\pm \mathrm{SD}=1.35 \pm 0.11$ ). Iverson (1985) found similar results when studying mud turtles Kinosternon hirtipes; the SDI within 21 populations of this species ranged from 0.96 to 1.15 (mean \pm SD $=1.05 \pm 0.09$ ). These authors suggested that, although sampling error may bias findings, other localised environmental factors may act to introduce variation in SDI. Our results were based on necessarily small sample sizes of male turtles in most cases, but this strengthens the validity of our findings as it makes finding a spurious correlation less likely. Given that the correlation between male and female size in the same population is so strong, we suggest that selection pressures leading to existing sexual dimorphism in green turtles are likely to be similar among populations.

As a result of sexual dimorphism leading to males being the smaller sex (often termed reversed sexual dimorphism, RSD), much effort has been expended in generating hypotheses as to the evolutionary mechanisms present in raptorial birds, as RSD is widely exhibited in this group (reviewed by Catry et al. 1999, Massemin et al. 2000). There is one hypothesis which suggests selection for small male size, or inter-sexual selection, and 5 hypotheses which suggest selection of large female size. Of these, only (1) the reproductive effort hypothesis and (2) the starvation hypothesis could have any plausibility within the mating system of green turtles. The lack of pair bond, territoriality or courtship feeding precludes (3) the female dominance hypothesis, (4) intra-sexual selection hypothesis or (5) female supplementary feeding hypothesis. 
The reproductive effort hypothesis suggests that increased female size will be favoured by selection as result of larger females laying a greater number of larger eggs. It is well known that female size will have marked effects on the size and number of eggs in individual laying attempts (Hirth 1997). It is likely that increased body size will confer fitness, and the reproductive effort hypothesis would have some credence in green turtle mating systems as a mechanism leading to RSD.

The starvation hypothesis suggests that larger females will be able to cope with longer fasting times and therefore be able to breed earlier or under harsher environmental conditions. Although the green turtles nesting at Ascension and many other breeding areas must starve whilst en route and at the breeding site (Carr et al. 1974), this is not the case for all populations (Hochscheid et al. 1999). In addition, starvation is also present for males at the same breeding site. Therefore, although we cannot exclude this hypothesis as a mechanism, it appears less likely.

The hypothesis which suggests the selection of small male size, or inter-sexual selection hypothesis, in raptorial birds, can also be extrapolated to green turtles. This proposes that smaller males may be more efficient at foraging, defending territories or performing nuptial displays, and are more readily chosen by females. Although no territorial defence or brood feeding are present in this species, what appear to be elaborate nuptial displays are undertaken (Booth \& Peters 1972). However, stabilisation selection of male size may be in operation as it is possible for a male to be too small for some females in the population. Although Limpus (1993) found males to be significantly smaller than females in 1 mating population, there did not appear to be assortative mating, with no correlation existing between sizes of individuals in mating couples. However, he did record repeated unsuccessful mountings by a small male trying to mount a large female.

Limpus (1993) also recorded unsuccessful mounting in males which had sustained severe damage to either forelimb claws or the tail. These carefully recorded anecdotes highlight the importance of the secondary sexual characteristics that will be extremely important for staying in a mounted position in the face of intrasexual agonism that is common in this species. In addition to the primary male, there are often a number of other males in attendance (Harrison 1954, Green 1979, Limpus 1993). These 'satellite' males joust (Harrison 1954), bite and can cause severe damage, especially to the trailing edge of the flippers of other males (Green 1979, Limpus 1993). However, it has been suggested (Jessop et al. 1999) that as only a relatively small proportion of mating couples have satellite males, this aggression is not the primary inter-male tactic for mate acquisition. If fighting were important, it would be expected that selection for large male size would have been in operation. Detailed endocrinological work by Jessop et al. (1999) has suggested that the hormonal mechanisms in males of this species are designed so that androgens are able to fluctuate in response to aggression and other mating activities. Stress-induced corticosterones elevated as a result of courtship damage possibly lead to the lowering of androgen levels, facilitating the cessation of mating in affected individuals.

This work has demonstrated the relationship between the timing of mating and nesting in green turtles. Strong evidence has been presented that the timing of the nesting season may be driven by temperature and that mating is dictated by the arrival of females at the breeding ground. There is a clear and consistent pattern of sexual dimorphism in this species. Although different versions of the reproductive effort, starvation and inter-sexual selection hypotheses could account for the demonstrated patterns of sexual dimorphism in green turtles, none of them are mutually exclusive and they could be acting in concert. To further this area of investigation, detailed studies are needed to ascertain the timing of arrival, duration of stay and reproductive success of known individuals of each sex.

Acknowledgements. This work was supported by grants to G.C.H., A.C.B. and B.J.G. from the Natural Environment Research Council of the UK (NERC), the Department of the Environment, Transport and Regions (DETR) Darwin Initiative programme, Foreign and Commonwealth Office Environment Fund for the Overseas Territories. It was carried out in conjunction with the Ascension Island Administrators, HH Roger Huxley and HH Geoffrey Fairhurst. The fieldwork would not have been possible without the efforts of Darwin Initiative Turtle Wardens and the help of the many regular volunteer track rakers and turtle weighers. We are grateful for the additional logistical support of Ascension Island Services, Cable and Wireless, Computer Services Raytheon, First Ascension Scout Group, Johnny Hobson, Merlin Communications Ltd, Dave Rayney, Reed Family, Royal Air Force, the United States Air Force, Wallace J. Nicholls. The RAF Meteorological Office at the Ascension Island Airfield for the generously provided weather information. Claudio Bellini, Steven Kolinsky and Hasan Orek all provided unpublished data. The manuscript was improved by the comments of Matthew Godfrey, Mike Frick, Michael Coyne and Andrew Kelly and 2 anonymous reviewers.

\section{LITERATURE CITED}

Ackerman RA (1996) The nest environment and the embryonic development of sea turtles. In: Lutz PL, Musick JA (eds) The biology of sea turtles. CRC Press, Boca Raton, p 83-106

Bailey NTJ (1981) Statistical methods in biology. Hodder and Stoughton, London

Baker JR (1938) The evolution of breeding seasons. In: De 
Beer GR (ed) Evolution: essays on aspects of evolutionary biology. Clarendon, Oxford, p 161-177

Balazs GH (1980) Synopsis of the biological data on the green turtle in the Hawaiian Islands. NOAA Technical Memorandum, NMFS SWFC-7

Balazs GH (1983) Recovery records of adult green turtles observed or originally tagged at French Frigate Shoals, Northern Hawaiian Islands. NOAA Technical Memorandum, NMFS-SEFSC-36

Balazs GH, Ellis DM (2000) Satellite telemetry of migrant male and female green turtles breeding in the Hawaiian islands. In: Abreu-Grobois FA, Briseño-Deuñas R, Marquez R, Sarti L (eds) Proceedings of the Eighteenth Annual Symposium on Sea Turtle Biology and Conservation. NOAA Technical Memorandum, NMFS-SEFSC-436, p s3-s5

Bass AL, Lageux CJ, Bowen BW (1998) Origin of green turtles, Chelonia mydas, at 'sleeping rocks' off the northeast coast of Nicaragua. Copeia 1998:1064-1069

Berry JF, Shine R (1980) Sexual size dimorphism and sexual selection in turtles (Order: Testudines). Oecologia 44: 185-191

Bolten AB (1999) Techniques for measuring sea turtles. In: Eckert KL, Bjorndal KA, Abreu-Grobois FA, Donnelly M (eds) Research and management techniques for the conservation of sea turtles. IUCN/SSC Marine Turtle Specialist Group, Washington DC, Publication 4, p 111-114

Booth J, Peters JA (1972) Behavioural studies of the green turtle Chelonia mydas in the sea. Anim Behav 20:808-812

Bowen BW, Meylan AB, Ross JP, Limpus CJ, Balazs GH, Avise JC (1992) Global population structure and natural history of the green turtle (Chelonia mydas) in terms of maternal phylogeny. Evolution 46:865-881

Broderick AC, Godley BJ (1996) Population and nesting ecology of the green turtle, Chelonia mydas, and loggerhead turtle, Caretta caretta, in northern Cyprus. Zool Middle East 13:27-46

Broderick AC, Godley BJ (1997) Observations of reproductive behaviour of male green turtles (Chelonia mydas) at a nesting beach in Cyprus. Chelonian Conserv Biol 2: 615-616

Bustard R (1972) Sea turtles: their natural history and conservation. W Collins \& Sons, London

Caldwell DK (1962) Carapace length-body weight relationships and size and sex ratio of the northeastern Pacific green turtle Chelonia mydas carrinegra. Los Angeles Cnty Mus Contrib Sci 62:1-62

Carpenter CC, Ferguson GW (1977) Variation and evolution of stereotyped behaviour in reptiles. Biol Reptil 7:335-554

Carr AF (1952) Handbook of turtles: the turtles of the United States, Canada and Baja California. Cornell University Press, New York

Carr A (1975) The Ascension Island green turtle colony. Copeia 1975:547-555

Carr A, Hirth H (1962) The ecology and migrations of sea turtles 5: comparative features of isolated green turtle colonies. Am Mus Novit 2091:1-41

Carr A, Ross P, Carr S (1974) Inter-nesting behaviour of the green turtle Chelonia mydas at a mid-ocean breeding ground. Copeia 1974:703-706

Catry P, Phillips RA, Furness RW (1999) Evolution of reversed sexual size dimorphism in skuas and jaegers. Auk 116: 158-168

Clutton-Brock TH, Harvey PH, Rudder B (1977) Sexual dimorphism, socio-economic sex ratio and body weight in primates. Nature 269:197-200

Comuzzie DKC, Owens DW (1990) A quantitative analysis of courtship behaviour in green sea turtles (Chelonia mydas). Herpetologica 46:195-202

Darwin C (1874) The descent of man and selection in relation to sex. Hurst, New York

FitzSimmons NN (1998) Single paternity of clutches and sperm storage by the promiscuous green turtle (Chelonia mydas). Mol Ecol 7:575-584

FitzSimmons NN, Limpus CJ, Norman JA, Goldizen AR, Miller JD, Moritz C (1997a) Philopatry of male marine turtles inferred from mitochondrial DNA markers. Proc Natl Acad Sci 94:8912-8917

FitzSimmons NN, Moritz C, Limpus CJ, Pope L, Prince R (1997b) Geographic structure of mitochondrial and nuclear gene polymorphisms in Australian green turtle populations and male biased gene flow. Genetics 147: 1843-1854

Frazier J (1971) Observations on the sea turtles of Aladabra Atoll. Proc R Soc Lond B Biol Sci 260:373-410

Frick MG, Slay CK, Quinn CA, Windham-Reid A, Ryder CM, Morse LJ (2000) Aerial observations of courtship behaviour in loggerhead sea turtles (Caretta caretta) from southeastern Georgia and north-eastern Florida. J Herpetol 34: 153-158

Gibbons JW, Lovich JE (1990) Sexual dimorphism in turtles with emphasis on the slider turtle (Trachemys scripta). Herpetol Monogr 4:1-29

Godley BJ, Broderick AC, Hays GC (2001) Nesting of green turtles Chelonia mydas at Ascension Island, South Atlantic. Biol Conserv 97:151-158

Green D (1979) Galapagos sea turtles. Noticias Gal 38:22-25

Green D (1994) Galapagos sea turtles: an overview In: Schroeder BA, Witherington BE (eds) Proceedings of the Thirteenth Annual Symposium on Sea Turtle Biology and Conservation. NOAA Technical Memorandum NMFSSEFSC-341, p 65-68

Harrison T (1954) The edible turtle Chelonia mydas in Borneo: 2. Copulation. Sarwak Mus J 6:126-128

Hays GC, Godley BJ, Broderick AC (1999) Long-term thermal conditions on the nesting beaches of green turtles on Ascension Island. Mar Ecol Prog Ser 185:297-299

Hays GC, Adams CR, Broderick AC, Godley BJ, Lucas DJ, Metcalfe JD, Prior AA (2000) The diving behaviour of green turtles at Ascension Island. Anim Behav 59:577-586

Hays GC, Godley BJ, Broderick AC, Glen F, Nicholls WJ (2001) The movements and submergence behaviour of male green turtles at Ascension Island. Mar Biol 139:395-399

Hendrickson JR (1958) The green turtle Chelonia mydas in Malaya and Sarawak. Proc Zool Soc Lond 130:455-535

Hirth HF (1997) Synopsis of the biological data on the green turtle Chelonia mydas (Linnaeus 1758). Biological Report 97(1). US Fish and Wildlife Service, US Department of the Interior, Washington, DC

Hochscheid S, Godley BJ, Broderick AC, Wilson RP (1999) Reptilian diving: highly variable dive patterns in the green turtle Chelonia mydas. Mar Ecol Prog Ser 185:101-112

Iverson JB (1985) Geographic variation in sexual dimorphism in the mud turtle Kinosteron hirtipes. Copeia 1985: 388-393

Jehl JR, Murray BG (1986) The evolution of normal and reverse sexual dimorphism in shorebirds and other birds. Curr Ornithol 3:1-86

Jessop TS, FitzSimmons N, Limpus CJ, Whittier TS (1999) Interactions between behaviour and plasma steroids within the scramble mating system of the promiscuous green turtle Chelonia mydas. Horm Behav 36:86-97

Karl SA, Bowen BW, Avise JC (1992) Global population 
genetic structure and male-mediated gene flow in the green turtle (Chelonia mydas): RFLP analyses of anonymous nuclear loci. Genetics 131:163-173

Kolata GB (1977) Sexual dimorphism and mating systems: how did they evolve? Science 125:382-383

Kolinsky SP (1995) Migrations of the green turtle Chelonia mydas breeding in Yap State, Federated States of Micronesia. Micronesica 28:1-8

Lahanas PN, Bjorndal KA, Bolten AB, Encalada SE, Miyamoto MM, Valverde RA, Bowen BW (1998) Genetic composition of a green turtle (Chelonia mydas) feeding ground population: evidence for multiple origins. Mar Biol 130:345-352

Le Boeuf BJ, Reiter J (1988) Lifetime reproductive success in northern elephant seals In: Clutton-Brock TH (ed) Reproductive success. University of Chicago Press, Chicago, p 344-362

Limpus CJ (1993) The green turtle, Chelonia mydas, in Queensland-breeding males in the southern great barrier reef. Wildl Res 20:513-525

Luschi P, Hays GC, del Seppia C, Marsh R, Papi F (1998) The navigational feats of green sea turtles migrating from Ascension Island investigated by satellite telemetry. Proc R Soc Lond B Biol Sci 265:2279-2284

Massemin S, Korpimaki E, Weihn J (2000) Reversed sexual dimorphism in raptors: evaluation of the hypotheses in kestrels breeding in a temporally changing environment. Oecologia 124:26-32

Meylan PA, Meylan AB, Yeomans R (1992) Interception of Tortuguero-bound green turtles at Bocas del Toro Province, Panama. In: Salmon M, Wyneken J (eds) Proceedings of the Eleventh Annual Symposium on Sea Turtle Biology and Conservation. NOAA Technical Memorandum NMFS-SWFSC-32, p74,

Miller JD (1989) Marine turtles: Vol 1: an assessment of the conservation status of marine turtles in the kingdom of Saudi Arabia. MEPA Coastal and Marine Management Series, report 9. Ministry of Defence and Aviation, Kingdom of Saudi Arabia

Miller JD (1997) Reproduction in sea turtles. In: Lutz PL, Musick JA (eds) The biology of sea turtles. CRC Press, Boca Raton, p 51-81

Mortimer JA, Carr A (1987) Reproduction and migrations of the Ascension Island green turtle (Chelonia mydas). Copeia 1987:103-113

Owens DW (1980) The comparative reproductive physiology

Editorial responsibility: Otto Kinne (Editor),

Oldendorf/Luhe, Germany of sea turtles. Am Zool 20:549-563

Paton PWC, Messina FJ, Griffin CR (1994) A phylogenetic approach to reversed sexual dimorphism in diurnal raptors. Oikos 7:492-498

Peare T, Parker PG, Waite TA (1994) Multiple paternity in green turtles (Chelonia mydas): conservation implications. In: Bjorndal KA, Bolten AB, Johnson DA, Eliazar PJ (eds) Proceedings of the Fourteenth Annual Symposium on Sea Turtle Biology and Conservation. NOAA Technical Memorandum NMFS-SEFSC-351, p 115-118

Prange HD (1976) Energetics of swimming of a sea turtle. J Exp Biol 6:1-12

Pritchard PCH (1979) Encyclopaedia of turtles. TFH publications, NJ

Ross JP (1985) Biology of the green turtle Chelonia mydas on an Arabian feeding ground. J Herpetol 19:459-468

Ross JP, Lageux CJ (1993) Tag return from a male green sea turtle. Mar Turtle Newslet 62:5-6

Rostal DC, Alvarado J, Grumbles J, Owens DW (1990) Observations on the reproductive biology of the black turtle Chelonia agassizi at Playa Colola, Michoacan, Mexico. In: Richardson TH, Richardson JI, Donnelly M (eds) Proceedings of the Tenth Annual Workshop on Sea Turtle Biology and Conservation. NOAA Technical Memorandum NMFSSEFC-278, p 255-258

Shine R (1978) Sexual size dimorphism and male combat in snakes. Oecologia 33:261-268

Shine R (1979) Sexual selection and sexual dimorphism in the amphibia. Copeia 1979:297-306

Tröeng S (in press) Observations of male green turtles (Chelonia mydas) on the nesting beach at Tortuguero National Park, Costa Rica. Chelonian Conserv Biol

Ulrich GF, Parkes AS (1978) The green turtle, Chelonia mydas: further observations on breeding in captivity. J Zool 185:237-251

Wibbels T, Owens DW, Rostal D (1991) Soft plastra of adult male sea turtles: an apparent secondary sexual characteristic. Herpetol Rev 22:47-49

Wikelski M, Hau H, Wingfield JC (2000) Seasonality of reproduction in a neotropical rain forest bird. Ecol 81: $2458-2472$

Witzell WN (1982) Observations on the green sea turtle Chelonia mydas of Western Samoa. Copeia 1982:183-185

Wood JR, Wood FE (1980) Reproductive biology of captive green sea turtles (Chelonia mydas). Am Zool 20:499-505

Submitted: February 26, 2001, Accepted: July 12, 2001

Proofs received from author(s): January 14, 2002 